\title{
Miranda
}

Revue pluridisciplinaire du monde anglophone /

Multidisciplinary peer-reviewed journal on the English-

speaking world

5 | 2011

South and Race / Staging Mobility in the United States

\section{Representing the Dark Other: Walker Percy's Shadowy Figure in Lancelot}

\section{Gérald Preher}

\section{OpenEdition}

\section{Journals}

\section{Electronic version}

URL: http://journals.openedition.org/miranda/2329

DOI: $10.4000 /$ miranda.2329

ISSN: 2108-6559

Publisher

Université Toulouse - Jean Jaurès

\section{Electronic reference}

Gérald Preher, "Representing the Dark Other: Walker Percy's Shadowy Figure in Lancelot", Miranda [Online], 5 | 2011, Online since 29 November 2011, connection on 16 February 2021. URL: http:// journals.openedition.org/miranda/2329 ; DOI: https://doi.org/10.4000/miranda.2329

This text was automatically generated on 16 February 2021.

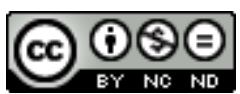

Miranda is licensed under a Creative Commons Attribution-NonCommercial-NoDerivatives 4.0 International License. 


\title{
Representing the Dark Other: Walker Percy's Shadowy Figure in Lancelot
}

\author{
Gérald Preher
}

1 Most southern writers have rooted their fiction in the region they come from, but not all of them adopt the same stand. Some ignore the presence of the dark other, others describe white people's hatred for whom they perceive as inferior beings, while the greater number makes use of the specific bond uniting whites and blacks, picturing the ambivalent relationship between children and their mammies in white households, interracial friendships or intimate relationships. For instance, Shirley Ann Grau, in The Keepers of the House, has exposed white people's reluctance to acknowledge the importance of African-Americans in their background. In the course of the narrative, her main character is forced to face the truth and accept the role that her grandfather's maid and mistress played in her life. In keeping with the idea that a change of stance on the part of white southerners is urgent, Grau penned, for Cosmopolitan, a lengthy article entitled "The Southern Mind" in which she explores various issues related to race and uses interviews with people throughout the South. Published in 1964, just like her novel, the essay makes it apparent that most Southerners are not ready to accept change: "The South enjoys its separateness and wants to keep it, while having the benefits of the economy of the rest of the country" (Grau 1964, 38). Although she clearly condemns her region for its stagnation, Grau emphasizes the changes that she has witnessed so far "in every field: education, civil rights, jobs" (Grau 1964, 40); she means to call the American reader's attention to the foundations of the South:

It isn't all hate and struggle. There are memories of pleasant associations, memories buried indelibly in the mind of every middle-class child. Memories of a classless, colorless world. Memories of innocence before the fall. (Grau 1964, 48)

Like Virginia Durr, with whom Fred Hobson deals in his book But Now I See, Grau's goal is to trace back "the origin of a doubt" (qtd. in Hobson 123) to make people understand that class and race cannot be used to evaluate an individual's position in a given society. It might be utopian to think that the gap between people of different colors can 
fully be bridged, but as Hobson suggests, it is only at the "intersection [between paradoxes and contradictions] that any honest discussion of contemporary southern life increasingly must lie" (Hobson 147). Walker Percy's comments on the race issue go in the same direction:

I don't mind saying or writing what I think on the social issues or the race issue in the South. [...] And when any writer in the South pretends he can write a novel and ignore the social issue of the Negro, something is wrong. (Cremeens 17)

My aim here is to study how in his 1977 novel Lancelot ${ }^{1}$ Percy tries to make sense of the paradox inherent in the South and succeeds in toning down the eponymous character's oft-commented upon violence by picturing his relationship to Elgin, his AfricanAmerican house help. The phrase "shadowy figure" used in the title of this article can thus apply to both characters: Lancelot is a man isolated in the "shadowy world" of his pigeonhole, trying to pull the strings as if he were the behind-the-scenes operator, and Elgin ends up being an intermediary between Lancelot's ordinary life and his wife's secret adventures. As a consequence, Lancelot and Elgin can be perceived as mirrors or doubles of each other (the white knight/the black knight). In the novel, Percy provides a thought-provoking treatment of the racial issue at the core of the southern experience and illustrates C. Hugh Holman's concept of the South as "a riddle union of opposites" when he emphasizes the complexity of the region's main features: "calm grace and raw hatred," alongside "polished manners and violence" (Holman 180). As Holman explains, "The southern writer has been uniquely equipped by his history to draw the symbol of guilt and to serve, himself, as an example" (Holman 196). Percy started reevaluating his social ethics when he joined the Roman Catholic Church in 1947 (O'Gorman 1999/2000, 70) ${ }^{2}$, as his depiction of African-Americans testifies. After focusing on the way race relations are presented in Lancelot's confessional narrative, I will analyze the portrait that emerges of a character that might eventually be referred to as Percy's "Artifical Nigger," for, like Flannery O'Connor's, he has "redemptive qualities" (O'Connor 78).

\section{Lancelot: Percy's "Southern Moderate”}

Farrell O'Gorman believes that Percy showed a true interest in the racial issue in his first two novels only, and that his novels after The Last Gentleman "show (...) little concern with race" (O'Gorman 1999/2000, 87). Adrienne V. Akins would certainly not concur with this critic since she recently devoted an essay to Love in the Ruins in which she concludes that "Percy depicts racism as not only a social problem but, even more significantly, as a sinful failure of love" (Akins 72). It seems to me that Percy's views also filter through Lancelot and that Elgin's presence and the importance allotted to him testify to the writer's concern for racial equality. Studies of this novel generally center on the eponymous character and his search for sin, forgetting that he is helped along the way by an African-American character whose friendship and faithfulness he values. ${ }^{3}$ So far, all the essays on Lancelot have dealt solely with Lancelot's immorality. In her study of the "search for moral standards," Bernadette Prochaska merely mentions Elgin as the person who tapes the adultery at the core of the book. In fact, even though Lancelot proves to be "immoral" as far as his reaction to his wife's betrayal is concerned, he shows a lot of concern for Elgin and thus somehow echoes Percy's moral standards on the racial issue. ${ }^{4}$ Lancelot can therefore be read as an example of Suzanne 
W. Jones' theory that "contemporary fiction set in the South can (...) help imagine new ways of racial knowing" (Jones 3).

Upon discovering his wife's adultery, Lancelot reflects on his life and makes the following assessment:

There I sat in my pigeonnier, happy as could be, master of Belle Isle, the loveliest house on the River Road, gentleman and even a bit of a scholar (Civil War, of course), married to a beautiful rich loving (I thought) wife, and father (I thought) to a lovely little girl; a moderate reader, moderate liberal, moderate drinker (I thought), moderate music lover, moderate hunter and fisherman, and past president of the United Way. I moderately opposed segregation. I was moderately happy. (L 24)

6 Everything in this description suggests that Lancelot feels incomplete. The inclusion of commentaries ('I thought') calls attention not only to the frailty of the facts he is exposing, but also to the gap between what he thought and what is. On the surface, he is a perfect Southerner but deep down he knows that there is an evil current underneath the smooth surface. What is interesting for my purpose is the reference to segregation for it places the novel in a specific context and suggests that, just like Lancelot's life, the South is in a precarious situation.

7 Percy's character is also reminiscent of comments made by the writer in an essay entitled "The Southern Moderate" (1957):

The Southern moderate (...) is a man of good will who is aware of the seriousness of the problem, is searching for a solution, but disagrees that the solution is simple and can be effected overnight. (Percy 1991, 95)

8 Indeed, Lancelot knows that the racial problem is one that cannot be set aside and he is happy to say that "The blacks after all were right, the whites were wrong, and it was a pleasure to tell them so" (L 59). When Lancelot explains that he "cannot tolerate this age" ( $L 154, L 156, L 157, L 159$ ), he not only associates it with his wife's betrayal of the marriage pact but also with a duel fought by one of his ancestors resulting from someone's exposing his origins-the fact that his father was a "Negro" ( $L$ 154). His conclusion, "I do not think men should butcher each other like animals" (L 155), proves his awareness that what he has done is not moral either. Indeed, as Robert $\mathrm{H}$. Brinkmeyer, Jr. reminds us, Lancelot "confidently asserts to Percival at one point that his actions were not evil but insignificant because they revealed nothing to him" (Brinkmeyer 38).

9 Recalling his scholarly work on the Civil War and the tourists from the Midwest he showed around Belle Isle, his family plantation, Lancelot mentions his desire to explain the racial issue to those foreign to the South:

Things are not so simple as they seem, I told them. There is something to be said for the master-slave relation: the strong, self-reliant, even piratical master who carves a regular barony in the wilderness and lives like Louis XIV, yet who treats his slaves well, and so help me they weren't so bad off on Belle Isle. (L 59)

Lancelot specifies that he did this "somewhat tongue-in-cheek," which implies that he sees the past with the necessary distance (he both mocks his ancestors and suggests that they were not too harsh on their slaves). As Susan V. Donaldson has put it, "Belle Isle and all that it represents no longer exist as a viable and organic part of everyday life but as objects rendered alien and autonomous by the pressures of a market economy" (Donaldson 68). Lancelot's making fun of his visitors' expectations and his 
comment that such people "hate the niggers worse than we ever did" (L 59) reinforces the point Percy makes in "Red, White, and Blue-Gray" when he writes that

The South has gotten rich and the North has gotten Negroes, and the Negro is treated badly in both places. The Northerners won and freed the slaves and now are fleeing to the suburbs to get away from them. (Percy 1991, 81)

11 By pitting the two points of view against each other, Percy means to prove that "Racial injustice is bad business" (Percy 1991, 97). In Lancelot, he addresses this issue by means of a satirical text so as to "[a]ttack the fake in the name of the real" (Percy 1991, 161) since northern hypocrisy is, in his mind, as detrimental to the black population as southern racism.

Comparing himself to his cousin Royal on what he calls "the 'nigger' business" ( $L 29, L$ 30), Lancelot ends up thinking that he actually does not do much himself:

[Royal] operated on blacks and whites alike and didn't call them niggers or even by their first names and sat them down together in his waiting room and did more for them than I did. He outdid me in the race thing. He did more and talked less. (L 30)

The absence of punctuation in the first sentence and the use of polysyndeton emphasize the fact that Royal's positive attitude towards African-Americans has no limit, while the length of the sentence contrasts with the short sentences following it. The paratactic introduction of his feeling of inferiority makes the gap separating Lancelot from Royal even wider. This episode marks a turning-point in his apprehension of "race" as a concept, since later on he seems more aware of the dark other's presence, both in his family background and in his present surroundings. He mentions dealing with "N.A.A.C.P cases" (L 71) and "helping Negroes" (L 87), thus making his involvement quite obvious.

Not only through his attitude as a budding activist, but also through his attacks on the twentie ${ }^{\text {th }}$ century-that age he considers intolerable-Lancelot can be seen as a rebel. As for the issue of "race," he explains that during the 1960s he made a point to disagree with some of his fellow Americans: "it was a pleasure to take the blacks' side: one had the best of two worlds: the blacks were right and I wanted to be unpopular with the whites. It was a question of boredom" (L 58). Lancelot's final comment sheds light on his subversive posture and raises suspicions about the sincerity of his commitment. Stylistically, the use of aposiopesis to separate the motives from the actual behavior makes it clear that cause and consequence are at odds. Lancelot may be defending this "UN-lost Cause" but at bottom he is trying to give meaning to his life by choosing an unlikely path. In addition, the unpopularity that Lancelot is talking about here is not foreign to his past lethal actions: he killed several people also because he wanted to fight against the sins of his contemporaries and, as a consequence, was sent to an asylum. When he notes that "the other day I ran into a black man with whom I had stood shoulder to shoulder defying angry whites" and that together "[they] won the fight" ( $L 59$ ), he makes his position clear: he is looking for social equality and truthfulness and wants to do right, no matter how much he might be hated for his political positions. ${ }^{5}$ Nevertheless, the encounter appears to be quite awkward and again, aposiopesis is brought into play: "We eyed each other uneasily. There was nothing to say. He told me he had had a slight stroke, nothing serious. We had won. So he bought a color TV, took up golf [...]" (L 59). The communication gap is made obvious through the use of indirect speech and reads as proof of Lancelot's uneasiness concerning his involvement. Still, the use of "we" to refer to both himself and the 
African-American shows that color no longer matters; a fact that is comically reinforced with the final comments on the television and on golf.

\section{A friend in need is a friend indeed: Elgin's changing status}

When Elgin makes his first appearance, he is shown "[sitting] in the slave chair, made by slaves for slaves" ( $L 43)$ and is therefore identified as a servant. However, Lancelot is quick to express his true feelings for him: "Elgin is, was, the only man, woman, or child I would trust completely outside of you, the more credit to him because it's required of you, isn't it?" ( $L 44$ ). Lancelot breaks the temporality of his narration by juxtaposing the present situation with his memories: the novel consists in his confession to his priest-friend Percival and, even if he often asks questions to his confessor, the reader only gets Percival's answers in the last pages of the novel and they are limited to "yes" or "no" (L 256-257). Elgin is more important than Percival because he played a part in the events Lancelot is now recounting ${ }^{6}$ and is part of Lancelot's daily activities: "I went to my office as usual, came home for lunch as usual, returned to the pigeonnier as usual, but instead of having three drinks and a nap, I sent for Elgin" ( $L$ 89). Elgin's importance increases to the point that he becomes Lancelot's eyes.

Indeed, Elgin first appears to be a kind of informer for Lancelot who wonders about his wife and the film crew that is shooting at Belle Isle:

"Elgin," I said. I had been thinking. "Did you happen to hear what time they got in

last night? The reason I ask is I heard somebody, maybe a prowler, around two."

Elgin looked at me. "They didn't come in till after three."

He knew who "they" were. (L 43)

This dialogue suggests that Elgin functions as the kind of "invisible man"7 Lancelot wants him to be ( $L 99)$ so he can report everything he sees ( $L 98)$. When Lancelot needs to ask him for "a favor" ( $(91)$, he puts himself on an equal footing with Elgin and they sit "in two slave chairs" ( $L 90)$. Before he explains what kind of favor he wants, Lancelot provides a very detailed description of Elgin (L 91-93) and, even though he does seem supercilious when he displays Elgin's feelings towards him and mocks the truth of the facts that have brought them together, there is little doubt that he values Elgin as an individual: "Elgin was smart, Elgin was well educated. Elgin could read and write better than most whites" ( $L$ 92). In addition, no matter how he puts it, Lancelot did save Elgin's family from the KKK. (L 92) and helped him get a scholarship (L 91)-ample proof of his concern for the man. In fact, this sounds like misplaced modesty and confirms that Lancelot wants to be perceived as a "tough guy" devoid of feelings. Like some of the writers Suzanne Jones studies in Race Mixing, Percy seems to "have found a way to model better interracial relationships or promote racial reconciliation without succumbing to 'friendship orthodoxy' or 'the integration illusion'" (Jones 15). Lancelot's telling Elgin "II want you to do [me a favor] without further explanation on my part'" ( $L 91)$ and Elgin's accepting to play the game makes their relationship one of complete intersubjectivity ${ }^{8}$ and trust. Lancelot observes: "Elgin, I do believe, would do what I asked, not out of gratitude (a very bad emotion as both he and I knew), but because he liked me and felt sorry for me" (L 94)-a revealing comment implying that in Percy's aesthetics, interracial friendship is possible. Lancelot admires Elgin for his scientific look on everything ( $L 100)$ and his fondness for the man is clear in many 
instances when he mentions his smile ( $L 99, L 100$ ) - in a way that goes against the common racial cliché-or his general attitude towards life: "Find happiness in problems and puzzles and mathematical gold bugs" (L 101). ${ }^{9}$ In some of their exchanges the idea that they belong to different races even disappears: "In his triumph [Elgin] permitted himself to be what he was: a twenty-two-year-old Southern youth who smiled and laughed a great deal" ( $L 100)$. At this specific moment, the color of Elgin's skin is not important for what Lancelot sees is only a comforting presence.

The favor Lancelot is asking for is that Elgin keep track of everyone's "comings and goings" so that he can get "the whole picture" ( $L$ 97). Although there is no further explanation as to what Lancelot is precisely looking for, the intimacy that the two characters share tells volumes: "[Elgin's] single swift opaque look told me he did understand. Understood and agreed. Understood even that there was something I needed to know but didn't want to tell him, nor did he want me to" (L 97). Their pact is sealed in secrecy, which explains why Elgin finds it difficult to read his report out loud after a night of spying (L 124-125). He actually "puts distance between himself and this business" ( $L$ 124) and starts calling everyone Mister and Miss, which, according to Lancelot's analysis, suggests that "he had retreated to being an old-time servant" ( $L$ 124). Such a regression into a subaltern role suggests that African-Americans deride the system that has long kept them in submission. When Lancelot asks for another favor, Elgin immediately agrees:

"Elgin, there are some things you and only you can do for me."

"I'll do them." (L 129)

In fact, Lancelot's plan is twofold: he has to phone his cousin who-thanks to the money Lancelot lent him (L 125) - owns the Holiday Inn where the film crew is staying, and arrange it so with him that the crew will eventually be housed at Belle Isle; that way, he will be able to set up his "cinéma-vérité" (L 128). Elgin is to be his cinematographer:

"I'm asking a favor of you. I need someone to help me and only you can do it. There are two reasons for this. One is that you have technical ability to help me. The other is that you are one of the two or three people in the world I trust. The others are probably your mother and father. I must tell you that it is a large favor because you will be doing it without knowing why." (L 140-141)

The shift in subject in this chain of sentences exposes Lancelot's vulnerability: the first two and the last one use the first person singular and therefore place Lancelot in the position of the beggar, while in the two middle ones the subject is the second person, which conveys Lancelot's empowerment of Elgin. Elgin's role then is instrumental in the unfolding action-without him, Lancelot would never get proof of his wife's adultery on tape. Like Ellison's character, Elgin ends up playing with colors: he indirectly fills the white pages of Lancelot's story with black words. Thus, this empowering process shows that, if originally Lancelot's rebellion is against contemporary sinfulness, it eventually becomes one against racial or social injustice.

\section{Elgin's redemptive qualities}

Critics have generally condemned Lancelot for being too much of a Southerner. Gary M. Ciuba writes that he "commits that unpardonable sin of turning people into objects. Elgin, Lancelot's personal cinematographer and sound man, is reduced to his ancestral status as a slave..." (Ciuba 108). In fact, a close reading reveals something totally 
different: Lancelot does say that "[Elgin was] in a sense 'my nigger'; and my watching him, waiting for him, was piece and part of the old way we had of ascribing wondrous powers to 'them,' if they were 'ours'" (L 142); but he introduces this comment as an "odd thought," which testifies to his awareness that it might be misunderstood. The many references to "sin" throughout Lancelot's confession and his desire to map out his own anatomy of that notion suggest he is involved in a project that is not foreign to the "conversion narratives" Fred Hobson studies in But Now I See. ${ }^{10}$ The above example indicates that Lancelot is "able to distinguish racial right from wrong at the point the tells his] story" (Hobson 6). As he recounts the events at Belle Isle, Lancelot proves his acute knowledge of the race problem-though, as a southern moderate, he is very careful what he says. There is little doubt that in the perfect world he foresees at the end of his confession, he will definitely give African-Americans a space of their own.

Telling the story allows Lancelot to step back and see things differently. Knowing Percy's interest in cinematic techniques, it seems that the interplay of light and darkness is a means of inscribing the race issue in the novel. The tables are somehow turned on racial discrimination since the African-American character is in charge of revealing the truth, of bringing the light. ${ }^{11}$ Oddly enough, when Elgin brings Lancelot the incriminating tape, the latter is filled with anger for he believes Elgin has played it beforehand:

Again a confession which does me little credit but it is important I tell you the truth. I had to admit I was angry because he had looked. Looked at the videotape. Then it was I discovered in myself what I had so often despised in others. For I had expected Elgin to do what I told him, be a technological eavesdropper and spy for me but not listen or look. More than that: I had expected that somehow he could not look-just as the hicks I despised believed that through some magical or at least providential dispensation the Negro bellboy cannot see the naked white woman in the same hotel room. Cannot even if he wanted to: she is somehow invisible. ( $L$ 180-181, Percy's emphasis)

Such a comment reinforces the idea that Lancelot's narrative also includes what Hobson would call "racial enlightenment" (Hobson 2): even though he finds it trying, the character is confessing that like any other Southerner he was hurt in his pride because a black man had "looked" at his Belle and seen her naked-on top of it all with another man. In this instance, Lancelot is protective of his wife's image and of his own. When Elgin explains that he just checked the beginning of the tape for quality, Lancelot is relieved; at the same time, his referring to Elgin as "the perfect nigger" ( $L 181)$ brings him back to the old southern way of treating people of color..$^{12}$ The ambivalence of Lancelot's feelings vanishes when he reflects that Elgin "still had the power to set things straight" (L 181); Lancelot thus has him reintegrate the realm of friendship he should not have removed him from. Even though Lancelot closes this episode with scornful comments on Elgin's behavior ( $L$ 182), he later behaves very considerately and saves him from the final cataclysm he has carefully orchestrated.

Lancelot's plan to avenge his honor is to blow up Belle Isle; but before he sets his plan in motion, he arranges to save those he feels have "good sense." Unsurprisingly, Elgin is among them and the dialogue that is reported shows how much Lancelot cares for his young friend. He gives him $\$ 75,000$ to secure his future, provided he uses the money for two things:

"One is to finish your education at M.I.T. despite the fact that your scholarship has run out. [...] The other is you want to marry your classmate Ethel Shapiro and buy a house in Woodale" (L 198). 
ancelot is aware that it is hard for black people to buy a house there and he admires Elgin's determination to do so against all odds. Lancelot's condition is simple: he wants Elgin to leave right away and take the "only people around here who have any sense with him" (L 199). Lancelot's gesture proves that he is not the "immoral" monster a lot of critics have described. On the contrary, his attitude towards Elgin shows that there is one sin he has come to terms with and overcome. Lancelot thus belongs to the texts Suzanne Jones believes can help "imagine our way out of the social structures and mind-sets that mythologize the past, fragment individuals, prejudge people, and divide communities" (L 17).

Lancelot's life started to crumble when he found out about his wife's betrayal and suddenly realized his existence had been wasted: "The moment I knew for a fact that Margot had been fucked by another man, it was as if I had been waked from a twentyyear dream" (L 107). His situation can be compared to that of the man in the first movie Binx mentions in The Moviegoer: although this man "found himself a stranger in a strange city," Binx thinks "things were not so bad after all" (Percy 1961, 4) since it gave the man a chance to start his life over. In much the same way, Lancelot notes: "There was a sense of astonishment, of discovery, of a new world opening up, but the new world was totally unknown" ( $L 42)$. Lancelot also becomes 'a stranger in a strange place' and believes this new world to be a world of freedom, a world with no boundaries, a world in which he will be able to act ( $L 107)$.

\section{Conclusion}

During his confession, Lancelot expresses his hopes for the future: "There will be leaders and there will be followers. [...] There will be men who are strong and pure of heart, not for Christ's sake but for their own sake" ( $L$ 178). Lancelot's dream is a dream of independence. In his society, one which will undoubtedly integrate ethnic minorities, "One will work and take care of one's own, live and let live, and behave with a decent respect toward others" ( $L 158)$. The idea of respect is central to understanding Lancelot's story, all the more as it is epitomized in his relationship with Elgin which is based on mutual commitment.

As Lancelot leaves the madhouse, he also puts an end to his confession and he feels cold:

You know the feeling of numbness and coldness, no, not a feeling, but a lack of feeling, that I spoke of during the events at Belle Isle? [...] The truth is that during all the terrible events that night at Belle Isle, I felt nothing at all. Nothing good, nothing bad, not even a sense of discovery. I feel nothing now except a certain coldness. (L 253)

The coldness he feels is a clue concerning his psychological development. He does not want to admit it but he has understood what went wrong, he can see his actions in a different light and can now describe them as "terrible." The use of the present and past forms of the verb 'to feel' also proves that he has learned something from the telling of his story. He may have failed in his search for evil, but he has succeeded in showing that he is human-with flaws, but also with qualities: bringing Elgin out of the shadowy world he was confined to does make Lancelot less objectionable. 


\section{BIBLIOGRAPHY}

Percy, Walker. The Moviegoer. 1961. New York: The Noonday Press, 1971.

---. The Message in the Bottle: How Queer Man Is, How Queer Language Is, and What One Has to Do with the Other. New York: Farrar, Straus \& Giroux, 1975.

---. Lancelot. New York: Farrar, Straus \& Giroux, 1977.

---. Signposts in a Strange Land. Ed. Patrick Samway, S.J. New York: Farrar, Straus \& Giroux, 1991.

Akins, Adrienne V. “'A Failure of Love': Racism and Original Sin in Walker Percy's Love in the Ruins.” Southern Quarterly 47:1 (Fall 2009): 65-73.

Brinkmeyer, Robert H., Jr. “Walker Percy's Lancelot: Discovery through Dialogue.” Renascence: Essays on Values in Literature 40:1 (Fall 1994): 30-42.

Ciuba, Gary M. “The Omega Factor: Apocalyptic Visions in Walker Percy's Lancelot.” American Literature: A Journal of History, Criticism and Biography 57:1 (March 1985): 98-112.

Cremeens, Carlton. "Walker Percy: The Man and the Novelist: An Interview" (1968). Rpt. in Conversations with Walker Percy. Eds. Lewis A. Lawson and Victor A. Kramer. Jackson: University Press of Mississippi, 1985. 16-35.

Donaldson, Susan V. “Tradition in Amber: Walker Percy's Lancelot as Southern Metafiction." In Walker Percy: Novelist and Philosopher. Eds. Jan Nordby Gretlund and Karl-Heinz Westarp. Jackson: University Press of Mississippi, 1991. 65-73.

Grau, Shirley Ann. “The Southern Mind: Black/White.” Cosmopolitan 157 (August 1964): 34-49.

---. The Condor Passes. New York: Alfred A. Knopf, 1971.

Hobbs, Janet. "Binx Bolling and the Stages on Life's Way." In The Art of Walker Percy: Stratagems for Being. Ed. Panthea Reid Broughton. Baton Rouge: Louisiana State University Press, 1972. 37-49.

Hobson, Fred. But Now I See: The White Southern Racial Conversion Narrative. Baton Rouge: Louisiana State University Press, 1999.

Holman, Clarence Hugh. “The Southerner as American Writer.” In The Southerner as American. Ed. Charles Grier Sellers, Jr. Chapel Hill: The University of North Carolina Press, 1960. 180-199.

Jones. Suzanne W. Race Mixing: Southern Fiction Since the Sixties. Baltimore: Johns Hopkins University Press, 2004.

Lawson, Lewis A. "Moviemaking in Percy's Lancelot." South Central Review: Journal of the South Central Modern Language Association 3:4 (Winter 1986): 78-94.

Marcel, Gabriel. Essai de philosophie concrète. 1940. Paris: Gallimard, Collection « Folio essais », 1999.

Mitgang, Herbert. “A Talk with Walker Percy.” 1977. In Conversations with Walker Percy. Eds. Lewis A. Lawson and Victor A. Kramer. Jackson: University Press of Mississippi, 1985.146-149.

O'Connor, Flannery. The Habit of Being: Letters of Flannery O'Connor. Ed. Sally Fitzgerald. New York: Farrar, Straus \& Giroux, 1979.

O'Gorman, Farrell. "Walker Percy, the Catholic Church and Southern Race Relations (ca. 1947-1970).” The Mississippi Quarterly: The Journal of Southern Cultures 54:1 (Winter 1999/2000): 67-88. 
---. Peculiar Crossroads: Flannery O'Connor, Walker Percy, and Catholic Vision in Postwar Southern Fiction. Baton Rouge: Louisiana State University Press, 2004.

Poe, Edgar Allan. "The Gold Bug." 1845. In Poetry, Tales and Selected Essays. Eds. Patrick F. Quinn and G.R. Thompson. New York: Library of America, 1996. 560-596.

Préher, Gérald. "Louisiana Gothic: Dark Waters, Fugitive Kind and Walker Percy's Imaginary World." In Gothic N.E.W.S. Volume 2: Studies in Classic and Contemporary Gothic Cinema. Ed. Gilles Menegaldo. Paris: Michel Houdiard Éditeur, 2010. 114-127.

Prochaska, Bernadette. "In Search of Moral Standards-Walker Percy's Lancelot.” Analecta Husserliana 85 (2005): 565-571.

Vauthier, Simone. "Mimesis and Violence in Lancelot." In Delta $N^{\circ} 13:$ Walker Percy. Eds. Ben Forkner and G. Kennedy. Montpellier: Université Paul Valéry, 1981. 83-102.

\section{NOTES}

1. All references to the novel are to Lancelot. New York: Farrar, Straus and Giroux, 1977, which will be abbreviated to $L$ throughout the article.

2. For a detailed analysis of the religious symbolism in the novel, see O'Gorman's essay and his book.

3. Lewis A. Lawson refers to Elgin as Lancelot's "faithful retainer" (Lawson 78) while Simone Vauthier mentions the character's mimetic behavior (Vauthier 84).

4. In a 1977 interview, Percy explained that, among other things, he intended the novel to remind the reader about "the [revolution] in the South, which was lost because of the wrongs of slavery" (Mitgang 147).

5. Incidentally, Lancelot claims that "[ $t]$ here are worse things than being disliked: it keeps one alive and alert" ( $L 59$ ). What he suggests is that difference is not a flaw but a quality, an element he uses to demonstrate that he can see clearly through his age and that, unlike many of his fellow Americans, he will not be fooled by appearances.

6. Lancelot's words make him sound like someone who does not want to hurt Percival's feelings or imply that what he is doing for him by listening is pointless compared to what Elgin did.

7. Elgin is also very much like the character Shirley Ann Grau derives from Ralph Ellison's famous narrator in The Condor Passes (see the opening words of her novel).

8. This term is borrowed from Gabriel Marcel's philosophy, which Percy had read closely. For Gabriel Marcel, "intersubjectivity" is the intimate, subjective relation between two persons. He explains: "Ce qui est en cause, c'est l'acte par lequel, au lieu de me défendre de l'autre, je m'ouvre à lui et me le rend en quelque façon pénétrable dans la mesure même où je deviens moi-même pénétrable pour lui. Au lieu que toute objectivité, et notamment celle du lui, se réfère à un certain dialogue entre moi et moimême, ce qui implique une relation triadique, - lorsque je suis en présence du toi, une unification intérieure s'opère en moi, à la faveur de laquelle une dyade devient possible" (Marcel 58). In an essay on The Moviegoer, Janet Hobbs clarifies what Marcel means: "Intersubjectivity is a unification which allows each person to transcend his own separateness through sharing with and caring for the other. Bringing joy and 
meaning and completeness to two lives, such a relationship combines aesthetic enjoyment with ethical responsibility" (Hobbs 47).

9. The allusion to Poe's story, "The Gold Bug" makes it possible to establish a parallel between Elgin and Jupiter, the caricatured African-American, for both men are totally devoted to a white person (either his employer for the former or his master for the latter). Poe's narrator describes Jupiter as a man "who had been manumitted before the reverses of the family, but who could be induced, neither by threats nor by promises, to abandon what he considered his right of attendance upon the footsteps of his young 'Massa Will' (Poe 561). Ultimately, in both Lancelot and "The Gold Bug", it is noticeable that the African-American character transcends racial boundaries by becoming a point of reference in the interpretation of the story, as one of Poe's characters has it: "Perhaps, after all, it was rather a desire than an actual belief;-but do you know that Jupiter's silly words, about the bug being of solid gold, had a remarkable effect upon my fancy?" (Poe 584).

10. Hobson uses this expression to refer to "a form of southern self-expression not seen until the 1940s", that is "works [...] which qualify as racial conversion narratives [and] in which the authors, all products of and willing participants in a harsh, segregated society, confess racial wrongdoings and are 'converted,' in varying degrees, from racism to something approaching racial enlightenment" (Hobson 1-2).

11. For an analysis of light and darkness symbolism see Préher.

12. Race relations are closely linked with the gender issue, especially in the South, where the preservation of the purity of white women was at the core of the racial divide. The fact that a white man asks an African-American to spy on his wife, thus tempting him, proves that Percy enjoys using clichés and questioning racial boundaries.

\section{ABSTRACTS}

Starting from Fred Hobson's reading of southern memoirs as "conversion narratives" in But Now I See (1999), this article aims at showing that Walker Percy's novel, Lancelot (1977), can be read as an attempt at depicting interracial relations in the South. Numerous critics have focused on the narrative voice and on Lancelot's unreliability as a narrator; yet Lancelot's various reflections on his bond with Elgin, his African-American help, show another facet of his character and make it possible to read his search for sin in a whole new way. True, he breaks several biblical commandments, but he also behaves like a good Christian with Elgin by treating him as a confident and privileged friend and not as an inferior being. By analyzing how the relationship between master and servant evolves and how Elgin gradually becomes an involuntary accomplice in the massacre that takes up much of the narrative space, the reader understands the true meaning of Lancelot's confession.

Partant du concept de conversion narrative qu'analyse Fred Hobson dans son ouvrage But Now I See (1999), cet article a pour objet de montrer que le roman de Walker Percy, Lancelot (1977), peut être lu comme une tentative de description des relations interraciales dans le Sud. Bien des critiques se sont intéressés à la voix narrative et au fait que Lancelot se révèle être UN narrateur 
peu fiable; pourtant, les diverses réflexions que propose le personnage sur ses liens avec Elgin, son domestique noir, montrent une autre facette de sa personnalité et permettent de relire sa quête du péché d'une toute autre façon. Certes, il enfreint nombre de commandements bibliques, mais il se conduit en bon chrétien en traitant Elgin comme UN confident et UN ami privilégié et non comme UN individu inférieur. En analysant comment les relations entre maître et subalterne évoluent et comment, de domestique, Elgin devient le complice involontaire d'une tuerie qui occupe une grande partie du récit, le lecteur comprend véritablement le sens de la confession que lui livre Lancelot.

\section{INDEX}

Keywords: race relations in the South, violence

Mots-clés: relations raciales dans le Sud, violence

\section{AUTHORS}

\section{GÉRALD PREHER}

Maître de Conférences

Institut Catholique de Lille

gerald.preher@gmail.com 